\title{
The Vichian Resurrection of Commedia dell'Arte: Michelet, Sand, and De Sanctis
}

\section{Rocco Rubini}

Here in the Italian theater are to be found the secrets of Italian life and character, more than in all the classical imitations put together. A history of the comedy and the tale in all their forms would be extremely instructive. And what precious material it would give us for a history of Italian society!

Francesco De Sanctis, History of Italian Literature

Abstract: This essay seeks to reconnect two intellectual events of major import in nineteenth-century France: Jules Michelet's "rediscovery" of Giambattista Vico as a viable source for a critical review of modernity's task and the scholarly, artistic, and moral accreditation of commedia dell'arte, something inaugurated by George and Maurice Sand in their landmark Masques at bouffons (1860). Together, I contend, these scholarly events mark turning points in the romantic revision of the Renaissance, Baroque, and Enlightenment legacies. In the first section of this essay, I examine Michelet's Vichian obsession, itself so often studied in isolation, to account for its hybridization with a specific brand of Italian Vichianism imported to France by Italian Risorgimento expatriates. As I explore in the second part of the essay, this connection informs the Sands' recuperation of commedia dell'arte, another important part of Italy's early modern legacy, as itself a Vichian event mediated by Michelet's historiography. In conclusion, this rapprochement will allow us to elucidate a larger reciprocation between French and Italian thinkers at the same time that Italians were reckoning with the legacy of the Risorgimento, as we see through the eyes of one of its major proponents, Francesco De Sanctis, who in his influential History of Italian literature (1870-1) reappropriated Vico to argue that the rebirth of Italy may depend on the obliteration of both its Renaissance and comic traditions. 


\section{Introduction}

In attempting to account for the emergence of the notion of commedia dell'arte retrospectively, from the vantage point of its reception in nineteenth-century France, Roberto Cuppone ventures a self-consciously bold claim: that it may never have actually existed "as a historical fact." Commedia dell'arte is an "abstraction," continually the subject of "nostalgic" sentiments and "utopian" aspirations. It is an "invention," he argues—or, what is much the same etymologically, a recovery—, that can be attributed to the collective "romantic dream" that, in France, "transfigured" a vile profession into a "metaphor of Art." This metaphor, in turn, contributed to the establishment of a modern European theatre (Cuppone, $C D A$ 25-26). ${ }^{1}$

Cuppone is well aware that he is raising a critical and controversial point in the study of commedia dell'arte; namely, he reflects on what kind of continuity can be found there, and what kind of relationship can (or ought to) be established between what commedia dell'arte was and what it eventually was imagined to be. Does a serious study of commedia dell'arte really mean forsaking the myths and legends that came to surround it? If so, does the suppression of those foundational romantic myths require a total re-writing of the vocabulary routinely employed to describe commedia dell'arte—or, in other words, to describe an elusive phenomenon whose essence, despite our best scholarly efforts, owes much to intellectual vagaries?

Scholars of commedia dell'arte deal with this impasse differently, but deal they must. In Il segreto della Commedia dell'Arte, for example, Ferdinando Taviani and Mirella Schino aver that the "way in which [commedia dell'arte] survives in the tradition of modern theater is closely interwoven with and superimposes itself on its history" (11). Commedia is often "obscured" by the legends that surround it. Attempting to unlock the "secret" that attends to its making as a tradition, which itself is invariably a composite legacy of creation and reception, would appear to necessitate a synchronic consultation of documents pertaining to its historical emergence and instrumental reinvention.

But straddling this ground is not always possible, or, some might say, even desirable. In their preface to a recently established journal dedicated to commedia dell'arte, Siro Ferrone and Anna Maria Testaverde seem bothered by the provocative implication of commedia's non-existence, claiming that the term "Commedia"

\footnotetext{
${ }^{1}$ Unless otherwise noted, all translations are my own.
} 
still suggests a set of "boundaries;" specifically, it suggests "a domain in the history of theater that runs from the early 1500s to the beginning of the 1800 s, which manifests a form of spectacular culture established on the preeminent role of actors, to whom everything else is to be reconnected," starting with the text, the staging, and so on. The hope seems to be that this designedly loose and inclusive truth may aid the scholar in rescuing commedia from the captivity of "thunderous misunderstandings" and "resounding deceptions" (vii). Ferrone continues to hold firm to this conservational program in his 2014 summa, La Commedia dell'Arte, in which he deploys a strict materialist philology in order to subvert any truism, including commedia's characterization as an art defined by masks and improvisation (5-6).

Meanwhile, another prominent scholar, Roberto Tessari, takes on Ferrone and Cuppone in the introduction to his own recent conspectus. In the theatrical "microcosm," he writes, the notion of commedia dell'arte is tantamount to "God" in the realm of metaphysics (v). Perhaps denying the existence of commedia proves useful in restraining "excessive enthusiasms," but history and myth cannot deny each other and should be made to collaborate instead (vi). Whether through the perspective of history or myth, commedia dell'arte tends to be approached "monolithically," that is, prevented from evolving through time as it surely did along a double and mutually influential axis. If one accepts that actors related to their art "mythically" from the beginning, then one must simultaneously accept that nineteenth-century passions regarding commedia were "historical." In other words, it makes sense to approach commedia not so much as a temporal "realm" or boundary but as a "way of conceiving" theatre (ix). ${ }^{2}$

Opinions and approaches vary and will continue to do so, but any critic who engages in a systematic study of commedia dell'arte (including the aforementioned) invariably, if more or less directly, pays tribute to George Sand and her son, Maurice, who together are credited with the romantic dream of commedia stemming from a private vision they shared while residing at their country estate of Nohant. There, in 1846, selected family members and close friends, including (it appears) Frédéric Chopin, began to spend their evenings playing games of

\footnotetext{
${ }^{2}$ Interestingly, these approaches are reflected in the form of the books mentioned: whereas Il segreto della Commedia dell'Arte is neatly divided between a first part dedicated to reception and a second part to the analysis of early-modern sources, Tessari leaves discussion of the "reinvention" of commedia for a final chapter, and Ferrone omits to mention Cuppone, to name just one critic, in the rich bibliography appended to his volume.
} 
charades. Given the family's financial resources and artistic leanings, these games soon developed into fully-fledged experimental theatre, a way to relive or re-experience firsthand the creative mystery of Italian-style comedy. According to George's recollections,

During the long winter evenings, it must now be some thirty years ago, I came up with the idea of creating for my family a theater reinvented on that old Italian model known as commedia dell'arte. That is, on plays whose improvised dialogue was drawn from a written scenario hanging backstage.

They were reminiscent of the charades that one plays in society and that more or less develop according to the group's talent. That is how it all began. Little by little, words disappeared from the charades, and we performed some crazy sketches, then comedies of intrigue and adventure, and, finally, eventful and emotional tragedies. It all began with pantomime, according to Chopin's inspiration. He improvised at the piano while the children mimed scenes and danced clownishly. I will leave it to you to imagine how these admirable and delightful improvisations went to the players' heads and loosened their legs. He led them as he pleased, and, according to his whim, they went from being amusing to austere, from burlesque to solemn, from graceful to impassioned. We improvised costumes in order to play different roles, such that on seeing them appear the artist would adapt his music to their character. This went on for three nights, and then, once the master returned to Paris, we were all left wild with excitement, determined not to let go of the spark that had electrified us. ("Le théâtre des marionnettes" 2: 1249-50)

This form of diversion would remain a jealously guarded secret until, not unlike the members of the legendary early modern theatrical companies whom they emulated and whose secrets they believed they had tapped, the Sands yielded to the temptation to fix their art on paper.

The result, Masques et bouffons, published in two volumes in 1860, is at once a pioneering work of theatre historiography and an artist's handbook. It is not quite comparable to anything that preceded it, but in it the student of commedia dell'arte finds traces of every form of literature that seventeenth-century comedians 
wrote about their art. Like Flaminio Scala's Il teatro delle favole rappresentative, for example, Masques et bouffons offers a sample of canovacci, or scenarios. Like Pier Maria Cecchini's Discorsi, it can be read as an actors' manual. In addition, like Francesco Andreini's tributes to his wife Isabella, it offers biographical insights about the men and women whose lives were on stage. Masques et bouffons can also be read as a more sophisticated version of the meta-theatrical representations by late generations of comedians, from Niccolò Barbieri's Linavertito to Carlo Goldoni's Il teatro comico, who sought to reintroduce and standardize the nature of their art. Yet the added dimension provided by Masques et bouffons is to be found in the maschere, or characters, drawn by Maurice and etched by Alexandre Manceau, that ornament these volumes.

The obvious question here is this: Does the Sands' experimentalism-and the text that eventually embodied it-rightfully deserve to be inscribed in the tradition of commedia dell'arte? I would argue that it does, for I believe that, especially in the context of a creative practice and (un)written form (i.e., an art relying on hearsay), reception is an integral part of the historical subject and not just a dutiful aside or appendix. To be clear, Masques et bouffons pertains to the living history of commedia dell'arte to no less a degree than Scala's anthology of scenarios or Giorgio Strehler's notes for the staging of Goldoni's Servant of Two Masters. For this reason, then, I am inclined to turn Cuppone's bold assertion on its head: it is not that commedia never existed but, rather, if it ever did, then once and forever! To believe the latter goes against the notion that the truth of commedia dell'arte is to be recovered in chronological precedence-that Scala, for example, has a greater claim to ownership than the Sands. More important, it affirms the possibility of having distinct re-appropriations, along with their surroundings, converse through time in mutual enlightenment. This, in short, is my intention for this study of commedia dell'arte: to burst the encapsulated and isolated narrative of the Sandian venture, which, despite having been fully recovered and detailed alongside its archives (see Cuppone, Le théâtre de Nohant), has not yet been joined successfully with the larger intellectual history to which it belongs.

George Sand foresaw that her family's experimentalism would one day be worthy of a conte fantastique, or fantastic tale, but it is surprising that there has been little attempt to demythologize, as it were, this doubly mythopoeic endeavour (inventive of both a genre and a family legend). More specifically, it is surprising that scholars have not done more to reconnect it to the French experience of Giambattista Vico and to what the celebrated French historian Jules Michelet 
called "the little pandemonium of The New Science," the text that offered, according to Michelet, the "golden bough" for a descent into the shadowy world of the past (Mali 17-18). This essay, thus, seeks to reconnect two intellectual events of major import in nineteenth-century France: the rediscovery of Vico-a thinker who, with the advantage of historical and geographical distance, permitted a critical review of modernity's task-and the scholarly, artistic, and moral accreditation of commedia dell'arte — a form of art that was as quintessentially Italian as it was disreputable by the time of its resurrection at the hands of the Sands.

Together, I contend, these events mark definite turning points in the post-revolutionary romantic revision of the Enlightenment legacy. We find that this rather fluid epochal transition was framed by interconnecting narratives of Vichian appropriations. The intellectual history I propose is articulated in three parts. In the first section of this essay, I return to Michelet's Vichian obsession, itself too often studied (rather, either celebrated or denigrated) in isolation, to account for its hybridization with a specific brand of Italian Vichianism imported to France by Italian Risorgimento expatriates. This untold conversation, I argue, is instrumental to seeing the connection between Michelet's "invention" of the Italian Renaissance and his Vichian enthusiasm. In turn, as I explore in the second part of the essay, this connection informs our understanding of the Sands' recuperation of commedia dell'arte, another important part of Italy's early modern legacy, as an equally Vichian event.

This approach, finally, will allow us to elucidate some confrontations between French and Italian thinkers at the same time that Italians were reckoning with the legacy of the Risorgimento, as we see through the eyes of one of its major proponents, Francesco De Sanctis. The intellectual history that I propose seeks to reiterate and further a story of cultural reciprocation: reintegrating an Italian perspective rescues the story of French Vichianism from being understood too narrowly, that is, as a story about historiographers merely using Vico; meanwhile, attending to the French perspective helps uncover the ironies in the formation of Italian intellectual identity, where we find a foundational, yet complex, rapport between Italian thinkers and the Italian comic tradition.

\section{Giving and Receiving Modernity: A Shared Vichianism}

If Giambattista Vico may be said to have inspired and supported the rise of French nineteenth-century historiography, then it is well known that the credit goes to 
Jules Michelet. Following a momentous encounter with Vico in 1824, Michelet made it his mission to unearth the Italian philosopher in his first publication (in 1827), a loose and still contested translation of the 1744 New Science, retitled Principles of the Philosophy of History. This work, which was first announced in Le Globe on 2 September 1826 as an "exposé du système et des doctrines" of Vico, was self-consciously an adaptation rather than a translation, intended to popularize Vico in France and, thus, internationally. This was the intention, too, of the introduction, "A Discourse on the System and the Life of Vico," which Michelet appended to the work.

From the outset, Michelet's challenge was to prove that, by disdaining Descartes, or the French forma mentis of the past, Vico's genius was "prophetic" in that it might herald the France of the future, the very one that Michelet would set out to narrate and thereby create, in accordance with his favourite of Vico's claims: " $[\mathrm{H}]$ istory cannot be more certain than when he who creates the things also narrates them" (104). Michelet embraced this motto with the fervour of a true demiurge, especially in what he rightly considered the magnum opus of his very prolific career, that is, the History of France, an example of embodied historiography in which Michelet brought forth the "resurrection" of history. As Michelet stated in The People, if Thierry called history "narration," and Guizot called it "analysis," then he would name his empathetic historiographical method "resurrection," a name he was confident would last (The People 19). Michelet affirms with Vico that what one knows is that which one remakes, through the "naming" act of resurrection.

And what was it that Michelet named and resurrected, enduringly? Just as Vico's incommensurable Italian thought proved to be instrumental in Michelet's personal rebirth as an intellectual, the same was true for France as a whole and for Michelet's ambition to represent the consciousness of his nation. In order to draw a correspondence between himself and history, then, Michelet needed to trace France's modern legacy and the Revolution it wrought to a precursory event, indeed, to an all-Italian achievement that, like Vico's philosophy, yet awaited explication and vindication. This event, of course, was the "Renaissance," a term and a periodization that Michelet invented in the seventh volume, Renaissance (1855), of his monumental History of France.

As I began to argue elsewhere, Michelet's feat-namely, his invention or, better yet, his Vichian "resurrection" of the Renaissance—was a more collaborative 
event than is usually acknowledged. ${ }^{3}$ Namely, Michelet's Renaissance was to a certain extent, yet necessarily, informed by a group of Italian Vichians who were forced to relocate to France in the early nineteenth century. They included Giuseppe Ferrari, who was first to edit the complete works of Vico (1835-1837) and who emulated Michelet by writing a lengthy introduction, "The Mind of Giambattista Vico" (1837), modelled after Michelet's "Discourse." Ferrari's work, known in its French translation and elaboration as Vico et l'Italie (1839), attempted to contextualize Vico's contribution to the Italian tradition of thought since the sixteenth century. It thus amounted to a rare sustained attempt at characterizing the Early Modern Italian legacy as a whole.

Ferrari's methodology, it turns out, is highly relevant to our efforts to characterize the emergence of the Italo-French Vichian Renaissance of the nineteenth century. Ferrari was influenced by his teacher, Gian Domenico Romagnosi, a thinker devoted, through a Vichian revision of Enlightenment concerns, to the notion of incivilimento: the study of the dynamic processes (economic, moral, and political) rather than the static conditions of "civilization." Central to this pursuit, one that Romagnosi shared with Victor Cousin (who mentored Michelet and commissioned his translation of Vico), was the study of "genius" or individual mind as a heuristic technique by which to approach the nature of collective man and, once this relation was established, the comparative study of people. Romagnosi's celebrated treatise, On the Nature and Causes of Civilization (1832), which included a second part dedicated specifically to the "resurgence" of civilization in Italy, wavered between affirming individual nations' self-sufficiency in their progress and emphasizing their reliance or co-dependency on the progress of other nations - in Romagnosi's terms, on the interplay between the "native" and "dative" factors of incivilimento.

Romagnosi elaborated on his ideas in "Considerations on the Limits and on the Direction of Historical Studies," an essay written to introduce a volume, published in 1832, that included an Italian translation of Michelet's 1827 "Discourse" on Vico. Here, Romagnosi presses for the study of "positive civilization" (positivo incivilimento) and, as far as beginnings are concerned, the "positive origin" (origine positiva) of things, meaning that concrete, observable proof can be furnished by nature or tradition (2: 51-53). To those interested in walking a Vichian path, therefore, Romagnosi recommends relinquishing abstract principles and axioms and the search for unfathomable origins, favouring paying attention to visible

\footnotetext{
${ }^{3}$ See “The Vichian 'Renaissance'."
} 
continuities instead. For example, he calls for the study "of colonies, conquests, and of those companies of Thesmophoroi," that is, those ancient legislators and go-betweens whose connecting and mediating efforts between nations led to the progress of civilizations. Concluding his introduction, Romagnosi writes that, for a civilization to progress, sometimes it is necessary that it "intersect the destiny of another people, one able to bring things to another stage of development and to a much wider diffusion of the same" (2: 59).

Romagnosi's emphasis on the "dative" quality of culture and on the intersecting destiny of people is what sustains Ferrari's strategy in the introduction to Vico et l'Italie. In this text, he suggests that Vico is possibly a genius, but one who is too solitary, or too native and provincial, and therefore in need of rescue through external interference. Heedless of ruffling the egos of his more (or differently) patriotic countrymen, Ferrari maintains, albeit only in retrospect, that in France a translated Vico can finally make contact with the masses and discover his popularity. And what of the Renaissance? Ferrari tended to characterize Vico as the last Renaissance man, and in so doing he sacrificed a great part of the Italian cultural legacy to the prospect of Vico's rescue by the French. Indeed, if we follow Ferrari's argument, to popularize Vico means to rescue the Italian Renaissance, which, in its "native" confines, was a moment of decadence. If Ferrari would not take on this task, apparently Michelet would. It seems to be no coincidence that, on the heels of his encounter with Ferrari and Vico et l'Italie, Michelet turned more to the Renaissance in his lectures.

In the recently published notes for the lectures that Michelet gave at the Collège de France in 1840-1841, we see elements that potentially align with the "dative." He inaugurates his course of lectures (Lesson 1) with a claim about the "solidarity" of the modern world and with a call to transcend national histories. He follows this with the claim that modernity began with the French "discovery" of Italy in the fifteenth century, a bigger "revelation," he says, than the discovery of America by Christopher Columbus. What the French recovered on the other side of the Alps was none other than "freedom," "because Italy believed in freedom and in man, and not so much in God" (Cours au Collège de France 1:351-52). In Lesson 2, he claims that, as a consequence of this humanism, nations came to a better understanding of their individuality in contrast to the "false unity" of the religious Middle Ages (1: 355).

In the third lesson, Michelet argues that understanding the Renaissance is fundamental to understanding the present, as that moment is intimately connected 
to the "French Revolution, [which] began much earlier than we think, long before Voltaire and Rousseau, who are not the only ones responsible for it [...]" (1:357). Michelet dedicates Lessons 4 and 5 to introducing his "vital method" in historiography, a method intended to revitalize history through intimate knowledge of great individuals. This method finds perfect validation in Napoleon, who is introduced at this point as the living embodiment of a doubled-natured modernity: "There are many men within the life of each man. Napoleon is an Italian man who became French. In the first accounts he could not be more Italian; in the latest he is more French than the French. Civilization can suppress the races" (1:360). This claim points to the congenial Italo-French profile of the modern epoch.

Accordingly, anyone who wants to delve into "the destiny of humanity" will have to study the combined geniuses of Italy and France, and in the second part of the course (Lessons 10-15), Michelet introduces his students to the varieties of "genius of nations" (German, Austrian, Spanish, and Italian): "But the more nations are different, the more they feel the need to complement each other" (1: 374). This is especially true of Italy in relation to the northern nations, who are helplessly attracted to it (1:373). In a companion course in 1841, titled "Eternal Renaissance," Michelet describes Italy and France as "complementing" each other, and as having done so perennially, from Caesar's "discovery" of Gaul to the French "donation" of Scholasticism to the Italians who, with Thomas Aquinas, returned it to perfect form (1: 420). And yet, despite some reciprocity, Michelet cannot deny that, ultimately, France accrued to the detriment of Italy. The characteristic "comédie-italienne" of seeking the stranger ended up in a last, unprofitable barter: the exchange of Leonardo Da Vinci, "the most complete of spirits," for Charles VIII, the "most incapable one" (1:424). But it is the destiny of "superior people" to be "swallowed up," for "humanity nourishes itself on their substance" (1:434).

In the History of France, Michelet famously describes the encounter between France and Italy at the time of Charles VIII's Italian campaign at the end of the fifteenth century as a "shock" between two incommensurable "races," two "civilizations." A historical palingenesis occurred in the collision of two different epochs, the French Middle Ages and Italian modernity: "Thus one morning blundering barbarity clashed with high civilization; the clash of two worlds and, even more, of two ages that seemed so far from one another. A clash and a spark, and, from that spark, the column of fire termed the Renaissance" ("The Renaissance and the Discovery of the World and Man" 26-27). The Renaissance certainly was a native phenomenon; yet, if France had not become a "living organ" for it (in Michelet's 
words), a voice for that incommensurably foreign civilization, the Renaissance legacy might have died, choked in the airless confines of the Italian peninsula.

When we reconnect Michelet's work to Ferrari's and Romagnosi's works, its true colours reveal themselves. We can perceive more distinctively that Michelet's invention of the Renaissance was inspired by Vico and amounted to a reciprocation of sorts—-something returned to Italy "datively," albeit retrospectively, in exchange for the right and privilege of sharing Vico. As the official "resurrector" of Vico, Michelet translated or carried across a version of the Italian Renaissance that allowed France to rediscover "something of its own original nature," and to reassume "by this contact a capacity for greatness" (26-27). Michelet was well aware that this feat was not merely and dryly historiographical but existential as well, in that it amounted to a prise de conscience regarding the origins of one's identity, and as such it was potentially an endless Socratic quest to know oneself, a quest that deserved to be reiterated in other realms of knowledge.

\section{“À quoi bon le théâtre italien?"}

I would argue that a notable instance in which the resurrective Vichianism developed by Michelet was put into practice was George Sand's rehabilitation of commedia dell'arte. While it may be impossible to ascertain or define the extent to which George Sand pored over Vico's work, let alone the extent to which she understood the New Science (which, from her diaries, we know kept her up late a night), it does not matter. We have seen how, thanks to Michelet's translatio, Vico's New Science was immediately a Vichianism, in France more so than anywhere else. That is, it was turned into what Hayden White describes as one of those rare texts that are "primarily concerned with interpretation itself" and that "serve as repositories of interpretive strategies by which to make sense of a text in general, themselves included" (198-199). In this case, Vico offered a hermeneutics to be espoused against the epoch's positivism and intellectualism and to be applied in order to grasp France in its infancy, the shared past we call "Italy."

Right away, in her preface to Masques et bouffons, ${ }^{4}$ George Sand shows that she has thoroughly absorbed the lesson. She writes, "Classical Italy has been turned inside-out and upside-down. And she will be turned over again and forever: her past is inexhaustible in sublime and charming monuments" (MeB 1: vi). Vico (and Michelet) had made possible an empathic comparison with the formative, and

\footnotetext{
${ }^{4}$ This title is shortened to $M e B$ in citations.
} 
shared, Italian past. The Sands self-consciously wanted to extend this comparison to Italy's "farcical side" (côté burlesque), which would obviate the "shortcomings of our century," an era that George felt was steeped in and thwarted in its progress by "classification" and "compilations." With her work, George Sand sought quite directly what she called an "intelligent compilation," the mark of a new modernity heralded by a "true criticism":

One might even say that the author [Maurice], faced with the unknown, did not back down: he tried to seize a world of imagination whose tangible trace had, for the most part, disappeared. Improvisation, this fleeting spark of the Italian genius, had bestowed its brilliant spontaneity and held high the banner of satire for centuries, through all the vicissitudes of political and religious history, without anybody taking care to transmit the text from one century to the next, whether because people believed that merry things would last forever or because it seemed that the richness of Italy's heritage was a well that would never dry up. But if it is true that it is not running dry, it is also evident that everything is used: what is transformed becomes at times something new, transformations apparently so complete that one would be tempted to believe them totally separate. But this is not the case. And study always reinforces the conviction that nothing is absolutely new under the sun. ( $M e B 1$ : v-vi)

For the Sand family, experiencing commedia dell'arte personally, viscerally, amounted to an encounter with a primordial world of the past, at once mythical and real—a world that, being for the most part Italian, could be accessed only through that "Italian genius" or mind that Vico had come to represent in France.

In the avant-propos of Masques et bouffons, we see further evidence that the Sands, mother and son, were aware that their work elaborated on Michelet's illustrious precedent. Here, Maurice, after giving his own account of the origins of the family charades, offers a clarifying gloss on his mother's account:

So then, each character produced instinctively, without being conscious of it, a kind of dialogue that was, in its form, a resurrection, but one could very well say an exhumation of the primitive attempts of antiquity. It was once again the dialogue without rules of the first 
Atellan farces, the only difference being the presence of the public, because we were utterly alone. $(M e B 1: 2)$

With regards to actors (those who embodied the subject of the Sands' research), the Sands' method was an "exhumation," a corollary of Michelet's resurrective historiographical principle. Whether they realized it or not, "exhumation" brought them closer, etymologically, to Vico, who derived the "humanity" of man from his grave-digging activity (bumanare) and who founded his hermeneutics or humanism on the "unearthing" that is the study of language: "ex linguae latinae originibus eruenda," as Vico specifies in the subtitle of On the Most Ancient Wisdom.

In his preface, Maurice goes on to explain that the game soon developed into an activity that required competence. The first mise-en-scène was entitled "The ill-mannered Druid," which features a sleeping dog. The piece begins with a young lover singing his poems to the feigned music of a string-less guitar. Suddenly, the dog leaps on stage, irritated. The Druid, who has been waiting for an altogether different cue, is seized by "innate inspiration" and begins sacrificing the "wild beast" on a large stone. At this point, the lover leaps to the defence of nature's representative. The blows are all too real, as a third character, a female Druid, also jumps into the brawl. Chaos ensues. What has just occurred?

What happened to the script? One forgets about it, one transforms it, incidents add up, scenes follow one another interminably with a logic of their own, but without restraint as to render a conclusion impossible. One by one we all gave in to exhaustion and vacated the stage: there the silence of the forest reigns, dust settles, lights dim, and the little dog dozes off to the notes of a piano, fading under the fingers of the daydreaming musician.

Now, at dinner, the actors of this incomprehensible oeuvre confess to each other to have found themselves in an overexcited and enraptured state of mind. I was possessed by the Druid's absurd exasperation and transported, imaginatively, to a world that never existed, as if I, too, had been subjected to the need that forces a primitive being to express all of his impressions symbolically. (MeB 1: 3; emphasis added) 
Rephrasing Maurice's experience in even closer Vichian terms, one could say that the unrecorded history of some aspect of human culture-in this case the raw power of Atellan farces and their early modern imitation - are intuited or, better, sensually perceived before being studied and intellectually grasped. The actual practice of theatre, like the unmediated experience Vico had of myth, positively guards against the end result of a priori rationalism, or what Vico calls the scholar's conceit-a conceit that reduces the unknown to the known, the unfamiliar to the familiar, always bypassing, in its locked circle, the stage of wonder in which revelation is first sensed. The dog's response to the lover's song interrupts the texture of a premeditated artefact, allowing for the reintroduction of nature's spontaneity. It was this experience that led Maurice to conclude that theatre's involution occurred when it began to be based on scripted dialogues.

In this case, too, as with Michelet's Vichianism, the Sands' Vichian experiment can be seen in the context of the Italo-French conversations of the period. More precisely, the work of George and Maurice Sand furthered the comparative psychologism sought by the likes of, for example, Cousin and Romagnosi and their students, Michelet and Ferrari. In fact, again in her preface to Masques et bouffons, George specifies that the study of commedia dell'arte pertains not to art history, at least not uniquely, but to the comparative study of the "psychology of two nations: Italy, where it originated, and France, that received it [...]" (vi). France, after playing around for a while with the Italian maschere, refashions them to fit the mould of "the graces and ridiculousness, the passions and the whims, the qualities and the peculiarities of its people," to the extent that

this need to personify the various naïve or distorted instincts of humanity in types that have been called Harlequin, Pulcinella, Cassandre, the Captain, Pierrot, etc., did at one point become so common in both nations that one could have called, and indeed did call it, Italian-French Comedy [la comédie italienne-française]. But we should never forget that the precedent for this ingenious and zesty model belongs to Italy and that without this rich and curious precedent Molière would not have been able to create the true French comedy. (MeB 1: vi-vii)

We shall soon see how it was crucial to Sand's project to recast Molière from originator of modern theatre to, at best, its "improver" (a term that implies 
corruption, too). What merits emphasis here is that, like Michelet's Renaissance, which appeared in 1855, in the very midst of the Sands' experimentalism, the Baroque genre par excellence that is commedia dell'arte was redefined as a "dative" genre-something handed down from Italy to France and, as such, connecting one to the other as infancy and maturity are connected in the same individual. ${ }^{5}$

If the "comédie italienne" is a fil rouge connecting modern French theatre to the ancient form, then it can be traced genealogically to the beginning of history before Christianity, and through the Middle Ages, by following the history of its ideal types as they were carried over "on the carts of the charlatans and the stages of the travelling performers." "We see them mature, perfect themselves, and transform," says George, "together with those very nations that delight in their jeers and gibes" ("La comédie italienne," 250). In other words, by studying comedy, which is at once universal and perennial and reflective of the genius of specific nations, we can investigate what Vico called the "ideal eternal history traversed in time by the histories of all nations" (124). For example, Sand points us to Pulcinella, arguably the oldest of all the maschere, who derives from the figure of Thersites, that first rebel and scourge of "the oppression of slavery and vileness" whom Vico himself took as an emblem, as a "poetic character of the socii or famuli" who first fought for democracy in history (47).

When George Sand claims that the study of commedia dell'arte is not the study of "certain pleasant types," but the study of those "real characters" that can be hunted down into the most distant recesses of time, she is aware that their "reality" is indebted to the creative power of a humanity that, in Vico's and Michelet's words, makes itself ("L'humanité est son œuvre à elle-même"), and in making itself, it is best suited to tell the tale of its achievement. Actors, in George's account, are perfect examples of these "original makers." Indeed, in the performers of the past, in the recovery of their "mind," the necessary discrepancy between making and telling is bridged. This realization gave her insight into the nature of commedia dell'arte, which "must have been an art completely different from our own, in which the actor [like Vico's primitive poets] was really a creator, because he drew his role out of his own intelligence and created his type by himself [...]" (“Le théâtre et l'acteur" 1241-1242).

It will not do to search for the true versions of these stories in the modern world, a world that according to George Sand has lost its "wild originality and

\footnotetext{
${ }^{5}$ Seeking any and all help in translating Ruzante's "impossible language," Sand says she turned again and again to histories of the Renaissance, including Michelet's, no doubt (see Poli 326).
} 
naïve emotions." If the "primitive truth" is lost, it is because of the loss of a particular artistic unity:

I am not advancing the idea that the actors are generally superior to the writers who work for them. I am saying that there are some who are. By the same token, there are authors who are often very unfortunate and who complain justifiably about not finding intelligent interpreters for all of their roles. What I am saying, above all, is that theater will not be complete until the two professions are but one-that is to say, until the man able to create a good role will be able to really create it, drawing inspiration from his own emotions and finding within himself the right and prompt expression of the dramatic situation. (1243)

This is why George Sand set out to recover in the past, in a past more distant than that represented by Molière, the "hint" of a theatre that would be realized in the future ("J'ai pourtant acquis et je garderai toujours la conviction qu'il y a, dans le passé, l'ébauche d'un théâtre que l'avenir réalisera" [1242]). Her study of commedia dell'arte would prepare the way for an "era [...] in which the Shakespeares of the future will be the greatest actors of their century" (1243-1244).

There are echoes of both Jean-Jacques Rousseau and Vico in George Sand's comments, but it is the latter who seems to prevail when her bitter comments on a too "blasée," "perfectionnée," and "moutonnière" modern civilization give way to hope for a ricorso. Fuelling this hope was an achievement that Sand reserved for herself, which was her rediscovery of a perfect artist who could be an example for the future, namely, Ruzante:

Thanks be unto you, good Ruzante, a great dead man that we recovered from the dust of oblivion. His work, which is rare in Italy and utterly unknown in France, allowed us, finally, to contemplate Commedia dell'Arte as a healthy Muse comparable in grandeur to that of Shakespeare and Molière. (MeB 2: 77).

And Sand's "resurrection" of Ruzante in the mid-nineteenth century was, indeed, a feat if we consider that efforts to trace the origins of commedia dell'arte to Roman farce had been discredited; it is only recently that the quest for such origins, long 
abandoned, has started up again and refocused on Ruzante and the sixteenthcentury Venetian compagnie of buffoni. ${ }^{6}$

It is not hard to guess why Ruzante, discussed at length in Masques et bouffons, between "la chanteuse" and Stenterello, earns a prominent place in the Sands' resurrection of commedia dell'arte. After all, Ruzante, alone among many maschere, was once an actual man named Angelo Beolco. The so-called Homeric question, so exemplarily introduced by Vico, comes to mind when we consider the Sands' euhemeric approach to this living mask. Less is known about his life than even Shakespeare's, but Ruzante was considered by his contemporaries to equal Plautus as an author and Roscius, the famed Roman actor, as a performer (MeB 2: 77-78). If he had applied himself more, and sooner, to writing plays, then he would have merited the title of Italian Molière-not Carlo Gozzi or Carlo Goldoni, those "ungrateful successors who didn't even so much as mention him and who, perhaps, never even read [him]" (MeB 2: 114).

What Ruzante, or, rather, the living man Beolco, provided to the Sands was a concrete oeuvre waiting for resurrection. His plays gave them a bone to chew on, and a meaty one at that, amid the hearsay and the often undecipherable relics that make up the mute history of commedia dell'arte. The task of the Sands became "philological," all the more so because this plurilingual author who disdained Tuscanized high culture availed himself of every esoteric patois his country and surroundings could provide. "For love of him," George Sand writes in a letter, "I broke my head to translate on my own some dreadful dialects [...]" (Poli 326).

\footnotetext{
${ }^{6}$ See Peter Jordan, The Venetian Origins of the Commedia dell'Arte (New York: Routledge, 2014). The Italian prejudice against commedia dell'arte has long kept scholars from relating, let alone assimilating, Ruzante to the movement. See, for example, Ludovico Zorzi's comments introducing his magisterial anthology of Angelo Beolco's theatre: "Dopo la duplice prova, la via dell'imitazione latina è come già percorsa in anticipo, e il Ruzante si avvede di non avere alcun interesse a proseguirla. I modi dell'Arte sono ancora di là da venire, e non è detto che l'autore dell'Anconitana, precursore di un loro tipico schema, avrebbe potuto provare per essi una rinnovata attrazione. Dal quarto decennio del secolo si assiste nel teatro a una svolta manieristica, imperniata sulla imitazione dei classici e sulla discussione delle regole piú o meno arbitrariamente da essi ricavate, che metterà capo alla precettistica pseudoaristotelica della commedia erudita e al tecnicismo del pari conservativo della Commedia dell'Arte, entrambi preludenti al 'salto' barocco. In questo panorama radicalmente mutato, il Ruzante poco o nulla ha da dire: alla sua produzione, concentrata nell'arco di poco piú che un decennio, succede un decennio di inerzia, interrotto soltanto dalla Lettera all'Alvarotto, patetico documento della crisi che lo ha ridotto al silenzio.” In Ruzante. Teatro. Ed. Ludovico Zorzi. Turin: Einaudi, 1967. lvii-lviii.
} 
George, however, was not the type to dally in philological endeavours for their own sake. She apprehended Ruzante's language(s) with the intrusiveness of an anthropologist eager to infiltrate a newly discovered tribe. The "Ruzante dictionary" that she is said to have created with much difficulty afforded her restricted access into naturalité itself, into that blessed state of nature, which modernity and the France she inhabited had lost: "What was lacking was what in theatrical language we call natural. The natural is an imitation of nature. Our young improvisators were more than natural, they were nature itself" (Poli 326). In this, too, Ruzante, even more than Rousseau, was a guide and not a primitive himself but an early scourge of the dispassionate refinement of his times, against which he raised the banner of a new poetics that he, precocious counter-Enlightenment figure that he was, named snaturalité.

Such a poetics is exactly what George calls for in the preface to Les Vacances de Pandolphe, which begins with the programmatic and not at all rhetorical question, "À quoi bon le théâtre italien?" (What is the use, then, of Italian theatre?). She goes on, noting that everyone knows that the transition from an "Italian" to "a French school" of theatre was due to the remodelling efforts of Molière. The genius of the French playwright is unquestionable, yet something can and should be said of the "oblivion" he inadvertently brought about, an oblivion in his imitators that amounts to a loss of awareness. In effect, George puts this transmutation on stage and analyzes it as a theatre critic:

The Italians improvised in their language at the Italian court of Mazarin. Under Louis XIV, the French language became so beautiful that one would not want to hear any other on the stage. Italian comedians were forced to learn French as well as they could. But as soon as they were versed enough to amuse their spectators, along came the authorities who forbade them to infringe on the rights of the new French comedy. It is known that they proceeded to fight this for a long time, performing scenes divided equally between two languages, in which a character would respond in French to his Italian interlocutor, adroitly translating as it came out what the audience could not understand. They also tried to use an Italian so gallicized that one would have had to make an effort not to understand it. Then they came to the point of just sprinkling their French dialogue with

\footnotetext{
${ }^{7}$ On Beolco's poetics, see Ferguson.
} 
a few Italian phrases, and the day came when, with the permission of the king, Harlequin retained no more of his language than some interjections: Oimé! Diavolo! Per Dio! etc. Doctor Baloardo and Cinthio had a great deal of trouble adapting to it, while FiorelliScaramouche never really took to it, and would remain an inimitable mute more than anything else. (Les Vacances de Pandolphe 730)

The story of commedia dell'arte is one of diminishing returns. It began with perfectly understood improvisers bantering in their language, and it ends with their forced silence, their mute, animated bodies. This occurred at a point in which, in truth, what was once essentially Italian perhaps "no longer belonged to anyone inasmuch as it belonged to everyone" (730); it contained a talent or a spark readily recoverable in the Roman Atellans as much as in the French improvisations of Pont Neuf. But was this indeed the case? Sand is not entirely sure. Granted that Molière's reform was important and perhaps necessary, there remained something irreducible, forever foreign, that no French playwright, not even "the divine Molière," could carry over.

What is certain, again, is that nothing is owed to those late self-styled reformers of commedia dell'arte who came to the fore in Italy in the eighteenth century, namely, Gozzi and Goldoni-to whom the Sands dedicate a paltry few pages, almost a digression, in the conclusion of their work. If little or nothing remains of Gozzi's aristocratic fables, those "wetnurses' tales" for "infant-poets" that do not merit a place in the archives of commedia dell'arte, it was Goldoni who was the true "assassin" of the genre (MeB 2: 356). Goldoni brought a "death sentence" against commedia dell'arte by substituting his personality for that of his actors, whom he turned into mere mouthpieces for his unpatriotic tone, a tone inimical to theatre (MeB 2: 367-8). Goldoni's murder of commedia dell'arte, the Sands aver, was sanctioned by his French conversion.

\section{Enough Is Enough: The Italian Comic Complex}

George and Maurice Sand understood the import of their claims, not just for the history of theatre or for Romantic aestheticism, but in political terms. Composed in the era of the Italian Risorgimento, Masques et bouffons was published in 1860, like Jacob Burckhardt's The Civilization of the Italian Renaissance, on the eve of Italy's long-awaited unification, an event celebrated by these publications 
with the reclamation of the entirety of Italy's early modern legacy, Renaissance and Baroque. George Sand made sure to dispatch a copy of her son's feat to King Victor Emmanuel II, along with a captivating note ("This book is a tribute to the Italian genius and, among its more humble rights, it has that of being placed at the feet of the liberator of Italy [...]"; Poli 340-341). But to what extent could these Vichian resurrections, of Vico himself and, through him, of the Italian Renaissance and its comedy, be received by Italian intellectuals?

A revealing, albeit necessarily shorthanded, answer may be recovered through a close reading of Francesco De Sanctis, a committed Vichian and arguably the most influential codifier of post-Risorgimento intellectual patriotism. Elsewhere, I have characterized the Risorgimento as a movement founded intellectually on a "Renaissance shame," that is, predicated on redemption from the Italian Renaissance precedent (an epoch as nefarious politically as it was great culturally), and I identified De Sanctis's History of Italian Literature as a work entirely and essentially dedicated to such a spiritual emancipation (The Other Renaissance 73ff). What De Sanctis pinpoints as the "malady" of the Italian consciousness takes many forms in the History: it might be emblematically represented by the pedantry of the Renaissance letterato, the letterato's civic disengagement, or his formal affectation. But what lies at the core of this "malady," beyond its symptomatic manifestations, is a merry, mocking, humoristic —in a word, unserious—approach to life and the world.

We see superiority and inferiority complexes alike at play in the irresponsible, existential attitude of the Italian cultural elite, an attitude that was a long time coming and that swept aside everyone in its wake, according to De Sanctis in a remark concluding the "Cinquecento" chapter of his History:

The thing that is alive in all [of Renaissance] literature is not the tragic and not the fantastic, but the comic: a comic that is often obscene and superficial and mixed with alloy, which remains at the level of caricature [...]. This comic art had worn itself out by constant repetition and had sunk into being shameless and inartistic. (1: 458-60)

For De Sanctis, the "comic" is not just a form among others; rather, it acquires ontological status as the chief manifestation of the Italian spirit at one of its highest, that is, most expressive, moments. De Sanctis avers that the infinite 
Italian Renaissance he describes - the very epoch the History is escorting to a close in the nineteenth century — was a "comic cycle," in literary terms.

In the final two chapters of the History, "The New Science" and the "The New Literature," De Sanctis points to the early stirrings of an as yet inchoate rebirth into seriousness. Here, the malady now fully diagnosed, he ventures a prognosis: Italy, in terms De Sanctis borrows from Vittorio Alfieri, begins to be "unthought" as national sentiments are awakened, and a new Italian man, a most humourless one, begins to be modelled from scratch (De Sanctis 2: 888). The two early champions of the transition described by De Sanctis are without a doubt Vico and Goldoni. Although Vico's "scientific" reform made Goldoni's possible, it is by looking at the contexts surrounding Goldoni that we come to know the difficulties at hand. When Goldoni conceived of his reform, De Sanctis explains, "[comedy] was the only form of the old literature that still had life in it, and belonged peculiarly to Italy; it was the one form of Italian art that still survived in Europe [...]" (2: 866). At the turn of the seventeenth century (and later), commedia dell'arte may very well have been the most recognizable staple of Italian culture, but if this was so, it was the staple of a culture so compromised that it was no longer literary.

De Sanctis understands that Goldoni's "reform" was something much more sophisticated than the moralization of an anonymous inherited corpus; it was, rather, foundational, "the revival of the words, the restoration of literature to the place that belonged to it and with the honors that were due to it" (2: 870). Indeed, Goldoni's banishment of "the fantastic, the declamatory, and the rhetorical" was no less of an achievement than Galileo's slaying of the "occult" and "supernatural" in science (2: 869). He was preceded in some ways by Molière, yet his achievement was greater, given the circumstances: it took place in Italy, "the classical land of the academy and of rhetoric," a land where literature had worn itself out so much that "words were no longer the principal thing," and where even comedy, the lowest of forms, "was afraid to appear by itself," that is, barefaced and scripted, "without the help of the masks and the improvised lazzi of the Harlequins, Truffaldinos, Brighellas, and Pantaloons" (2: 870).

It is worth dwelling on this point because, in De Sanctis's view, transitions are not merely announced but are re-experienced as conquests of the common spirit. In the process, literature certainly changes, but so does the very physiognomy of the Italian man. At an important turning point, for example, we are told that Giuseppe Parini, who "never really manages to laugh" at the old "forms," at best 
"laughs with a wry mouth" while feeling nothing but "disgust and "contempt." It was Italy as a whole that "had laughed enough, and was laughing still with" Goldoni until a "redeemer," a "hero," a "gigantic solitary statue" came along, wagging his finger, to wipe that grin off her face, to "eliminate the irony" and "allow the disgust, anger, and contempt to rise openly and defiantly to the surface" (2: 885). This epiphanic hero was Alfieri, whose first feat was to supply his country, otherwise "ahead of all nations in all forms of literature," with the one form it lacked: tragedy (2: 887).

The birth of the new literature was an invigorating recycling of the Italian spirit and, as such, a heroic act. When De Sanctis juxtaposes Metastasio and Goldoni, for example, he does so to assert that the realism of the latter brought the heroic age to a close ${ }^{8}$ and, thus, according to a Vichian framework, brought rebirth into the age of man. Such a feat, of course, is not just literary but also spiritual and hence philosophical; in contemporary terms, it signals an epistemic turn. Accordingly, Goldoni's realism is not merely the product of a professional manipulation of the commedia a soggetto; rather, it bears witness to the assimilation of the achievements of those "new philosophers" to whom we owe "the first reconstruction of consciousness, the new world as opposed to aestheticism, the world discovered and illustrated by science" (2: 877). It was the likes of Giordano Bruno, Tommaso Campanella, Galileo, Paolo Sarpi, and Vico who made naturalism and criticism possible; it was they who sought "for reality behind the appearance," for "spirit beyond the forms," "for the real and the positive, and not in books but in the direct study of things." In short, it is they who first began looking "at things unveiled, in their substance and reality" (2: 773).

But for De Sanctis it is not necessarily the case that literature is an excrescence of science, for the opposite is equally true. After all, asks De Sanctis coyly, what was Bruno's first book? "It was a comedy_Il Candelaio (The Candle-bearer)" (2: 718). In other words, Bruno, too, is a man of his time and place-an Italian comedian. Yet if one compares him to another "renegade monk," Folengo, who "came out of his cloister denying God and spitting in the face of society," one sees Bruno's exceptionality. In Bruno, too, "there is satire and irony in plenty"; his plays may have "the basis [...] of Italian comedy from Boccaccio to Aretino," but he was disgusted by this, long before Parini expressed a similar reaction (2: 740). It is why Bruno raises an existential mirror to his face, in the "anti-prologue" of $I l$

\footnotetext{
8 "To paint from the real meant the end of the heroic as conceived in Italy-the end of Metastasio" (2: 862).
} 
Candelaio: "The Author, if ever you should see him, has a bewildered look on his face, as of a man who is forever contemplating the pains of hell [...]. [I]f he laughs it is only because others are laughing. As a rule you will see him disgusted, restive, and strange" (2:719).

If Italian philosophy was born out of comedy, it is natural that its climaxits little read and perhaps too precocious "bible," Vico's New Science-should offer a bracing corrective to the comic tradition, namely that "to remake society it is not enough to condemn it: it must be studied and understood" (2: 801). Vico's new science, "the Divine comedy of science," does something unique in inaugurating "real drama, the story of the mind in the world"; with this infusion of temporality, everything becomes narrative, that is, in a Vichian ricorso, everything becomes literature, albeit reformed:

A work of art was no longer regarded as an arbitrary and subjective product of the mind in its immutable rules and examples, but was a product, partly unconscious, of the spirit of the world at a given moment of its existence. [...]. With this changed point of view came a change in criteria. The literature of the Renaissance was condemned as classical and conventional, and the use of mythology was ridiculed. [...]. There returned to favour that old motto of Goldoni: "Paint from life; avoid falsifying Nature." (2: 927-928)

When we see De Sanctis's History for what it is-the story of the long process of Italian emancipation from the "comic"-, we see the false start of the Italian literary Renaissance made right. Moreover, this emancipation would not have succeeded to the same extent, if at all, if not for Vico and Goldoni, two authors who are rarely connected as intimately as they are by De Sanctis, who is able to see their spiritual affinity. It took a double-pronged reform, as much Vichian as Goldonian, to cure the Italian comic complex.

In Italy, as demonstrated by De Sanctis's major and vastly influential work, Vico helped forge a patriotic existentialism that centred on expunging the comic and its most representative form, the bodily form that is commedia dell'arte. And yet, a similar reconnection, a Vichian resurrection of commedia dell'arte, had already occurred in France at the time of De Sanctis's indictment, where, over the span of approximately 40 years, the convoluted new science of Vico was translated into a universal language; through such a restitution, the mute language of the zanni 
himself was decoded and, through George Sand, presented as the art of a (truly de-intellectualized) theatre of the future.

\section{Conclusion}

What, then, is the point of Italian theatre? In this essay, I have outlined how the Italian theatrical tradition, insomuch as it identified with the largely anonymous commedia dell'arte, could hold a most insightful mirror to the Italian consciousness, echoing what De Sanctis said 10 years after the publication of Masques et bouffons. One wonders if De Sanctis had it in mind to correct the Sandian apology of Italian theatre (as much as he wished to correct the contemporaneous fascination for the Italian Renaissance from Michelet to Burckhardt) when he asserted, in his History, that Italian spiritual salvation hinged on suppressing the Renaissance heritage and, at the same time, vanquishing its "comic" degeneration. De Sanctis's carefully wrought plan and injunctions lend an ironic, if not "comic," twist to the use of Italian sources by the French Romantic enterprise. Still, if what we call De Sanctis's Italian "Renaissance shame" and correlated "comic complex" were of Vichian origins through and through, then it would seem paradoxical that Vico himself had already attended not only to the "invention" of the Renaissance but, to an important extent, to the decriminalization of commedia dell'arte as well.

But is this intellectual history really paradoxical? A deeper grasp of his legacy confirms that Vico's appeal was mainly hermeneutical rather than literal, and, thus, "futural" in its ability to elucidate the future of the past. Consequently, then, applying Vico could have varied results depending on the discrete past experiences and future aspirations of Vico's readers, and, in the case of Vichians of the calibre of Michelet and De Sanctis, of the people or nations they felt they were representing. If it is illuminating to compare the ways in which Vico was interpreted in France and Italy in the nineteenth century, it is because this comparison illustrates the incommensurability of the two nations - not of their "minds" or "geniuses," as the contemporary literature averred, but of their historical development and self-awareness (or sense of agency) during the transitional epoch that was the nineteenth century.

Since Petrarch, at least, Italy had continuously expressed some ambivalence towards the French in the realms of literature, philosophy, and history, and it is to the credit of the French that they did not dismiss Italian criticism out of hand. After 1789, the French benefited from an awareness of Italian difference, 
in the way that an outward look always edifies, and they used it to enhance the experience of modernity when the alternative might have been to approach it in too solitary a manner. Unlike the Italians, the French saw Vico not so much as a means to develop a Counter-Enlightenment but more so as a way to integrate the French moment into the continuum of history and, thus, disseminate it.

\section{University of Chicago}

\section{Works Cited}

Cuppone, Roberto. CDA. Il mito della commedia dell'arte nell'Ottocento francese. Rome: Bulzoni, 1999. . Le théâtre de Nohant. 2 vols. Moncalieri: Centro interuniversitario di ricerche sul "Viaggio in Italia," 1997.

De Sanctis, Francesco. History of Italian Literature. Trans. Joan Redfern. 2 vols. New York: Barnes and Noble, 1968.

Ferguson, Ronnie. The Theater of Angelo Beolco: Text, Context, and Performance. Ravenna: Longo, 2000.

Ferrone, Siro. La Commedia dell'Arte. Attrici e attori italiani in Europa (XVI-XVIII secolo). Turin: Einaudi, 2014.

Ferrone, Siro, and Anna Maria Testaverde. "Presentazione." Commedia dell'Arte. Annuario internazionale 1 (2008), vii-viii.

Jordan, Peter. The Venetian Origins of the Commedia dell'Arte. New York: Routledge, 2014.

Mali, Joseph. The Legacy of Vico in Modern Cultural History: From Jules Michelet to Isaiah Berlin. New York: Cambridge UP, 2012.

Michelet, Jules. Cours au Collège de France. Ed. Paul Viallaneix. 2 vols. Paris: Gallimard, 1995.

. "A Discourse on the System and the Life of Vico." Trans. Ashraf Noor. New Vico Studies 26 (2008). 21-46.

. The People. Trans. John P. McKay. Urbana: U of Illinois P, 1973.

. "The Renaissance and the Discovery of the World and Man." The Renaissance Debate. Ed. Denys Hay. New York: Holt, Rinehart and Winston, 1965. 22-28. 
Poli, Annarosa. L'Italie dans la vie et dans l'auvre de George Sand. Moncalieri: Centre interuniversitaire de recherche sur le voyage en Italie, 2000.

Romagnosi, Giandomenico. Scritti filosofici. 2 vols. Florence: Le Monnier, 1960.

Rubini, Rocco. The Other Renaissance: Italian Humanism Between Hegel and Heidegger. Chicago: U of Chicago P, 2014.

. "The Vichian 'Renaissance' Between Giuseppe Ferrari and Jules Michelet." Intellectual History Review 26.1 (2016): 9-15.

Sand, George. "La comédie italienne." Questions d'art et de Littérature. Paris: Lévy, 1878. 249-256

."Le théâtre des marionnettes de Nohant." Oeuvres autobiographiques. Ed. Georges Lubin. 2 vols. Paris: Gallimard, 1971. 2: 1249-1276.

. "Le théâtre et l'acteur." Oeuvres autobiographiques. Ed. Georges Lubin. 2 vols. Paris: Gallimard, 1970. 1239-1244.

. Les Vacances de Pandolphe. Oeuvres complètes. Théâtre. Ed. Annie Brudo. 2 vols. Paris: Honoré Champion, 2014. 729-879

Sand, Maurice (ed). Masques et bouffons: comédie italienne. 2 vols. Paris: Michel Lévy Frères, 1860.

Taviani, Ferdinando, and Mirella Schino. Il segreto della Commedia dell'Arte: la memoria delle compagnie italiane del XVI, XVII e XVIII secolo. Florence: La Casa Usher, 1992.

Tessari, Roberto. La Commedia dell'Arte: Genesi d'una società dello spettacolo. Rome: Laterza, 2013.

Vico, Giambattista. The New Science. Trans. Thomas G. Bergin and Max H. Fisch. Ithaca (NY): Cornell UP, 1984.

White, Hayden. Rev. of Vico: A Study of the "New Science," by Leon Pompa. History and Theory 15 (1976): 186-202.

Zorzi, Ludovico (ed.). Introduction. Teatro. By Ruzante. Turin: Einaudi, 1967. 